\title{
Effect of Blended Fertilizer and Lime Application Rates on Grain Yield and Yield Component of Maize (Zea mays L.) in Omo Nada District, Jimma Zone Southwestern, Ethiopia
}

\author{
Alemayehu Abdeta \\ Oromia Agricultural Research Institute, Bedele Agricutural Reseach Center P.O. Box 167, Bedele, Ethiopia
}

\begin{abstract}
Maize (Zea mays L.) is one of the important food security crops and play significant role in the livelihood of most Ethiopians. However, the productivity is hampered by several biotic and abiotic factors including low soil fertility. This study was therefore; conducted to determine optimum rates blended fertilizer under limed and unlimed condition of acid soil on Maize in Omo Nada District, Jimma Zone Southwestern, and Ethiopia during 2017 main cropping season. The amount of lime that was applied at each location was calculated on the basis of the exchangeable acidity. The experiment used seven treatments; Control, NPS, NPSB,NPSB plus Recommended rate of Lime, NPSB plus $0.75 *$ recommended rate of Lime ,NPSB plus $0.50 *$ recommended rate of Lime and NPSB plus $0.25^{*}$ recommended rate of lime were laid out in randomized complete block design (RCBD) replicated across Seven farmers' fields in each location. Application of lime was dramatically improved soil pH from 4.5 to 5.28. Yield and yield components of Maize were significantly affected by integrated use of blended fertilizer and lime. Accordingly, Plant height, Grain Yield, Biomass Yield, Harvest Index and thousand kernel weight of Maize were obtained with application of NPSB plus recommended rate of Lime. Higher net return 15914 Ethiopia birr/ha with marginal rate of return of $557 \%$ of Maize was obtained with application of NPSB plus Recommended rate of Lime. Thus, integrated use of NPSB plus Recommended Lime is recommended for Maize production in acid soil of Omonada district and similar agro ecologies.
\end{abstract}

Keywords: soil pH, soil test, fertilizer recommendation, Yield

DOI: $10.7176 / \mathrm{JBAH} / 11-11-03$

Publication date:June $30^{\text {th }} 2021$

\section{INTRODUCTION}

Maize (Zea mays L.) is one of the most important cereal crops in the world. It ranks third among other cereals after wheat and rice (FAOSTAT, 2017). Maize is the most widely grown among cereal crops in Africa and a staple for around half the inhabitants in the continent. Maize accounts for almost half of the calories and protein consumed in Eastern and Southern Africa, and one-fifth in West Africa (Macauley, 2015). The low productivity of maize in Ethiopia is attributable to many factors: soil degradation, nutrient depletion, lack of improved variety, insufficient technology generation (Achalu et al.,2012).

Specially, soil acidity is one among the major factors limiting maize production and productivity in western Oromia, Ethiopia (Wakene et al., 2005). Currently, it is estimated that about $40 \%$ of arable lands of Ethiopia are affected by soil acidity (Taye, 2007). Lime is the major means of ameliorating soil acidy (Anetor and Ezekiel, 2007) because it has very strong acid neutralizing capacity, which can effectively remove existing acid. Lime is the major means of ameliorating soil acidy (Anetor and Ezekiel, 2007) because it has very strong acid neutralizing capacity, which can effectively remove existing acid.

Hence, soil fertility maintenance is a major concern in Ethiopia. Although there is a gradual increase in the total volume of fertilizers used in the country, low and unbalanced application rates per unit area of land mainly focusing on Urea and DAP fertilizers with low efficiency of the fertilizers (Getachew et al., 2009) and limited use of improved seeds (Dercon et al., 2009) have still remained major constraints for small farmers to get the best out of the input.

However, the contribution of lime with blended fertilizer on yield and yield attributes of Maize in Omonad district had not been determined. Therefore, the objective is to determine the effect of blended fertilizer (NPSB) on yield and yield components of Maize under acidic soil condition of in Southwestern particularly in Omonad District.

\section{Materials and methods}

Field experiment was conducted on maize during 2017 cropping seasons on acid soils in Omonad district Jimma zones, in South Western Ethiopia. Geographically, the woreda lies between latitudes of $7^{\circ} 17^{\prime}$ to $7^{\circ} 49^{\prime} \mathrm{N} 37^{\circ} 00^{\prime}$ to $37^{\circ} 28^{\prime} \mathrm{E}$ with altitude $1650-2200$ meters above sea level. The rainfall of the area is bimodal, with unpredictable short rains from March to April and the main season ranging over June to September. The minimum and maximum annual rainfall ranges from 1066 to $1200 \mathrm{~mm}$ with a mean annual temperature ranging from 18 to $25^{\circ} \mathrm{C}$ (SLMP, 2009). The dominant soils of the area was reported (Eyasu,2016) Nitisols and moderately to strongly acidic. soils 
have clayey in texture and strongly to moderately acidic in reaction.

\section{Site and farmer's selection}

The experiment was conducted in oromia region, Jimma zone Omo Nada District. The intervention kebles were selected based on maize production potential of the area. Farmers and Site selection from the district was made both by researcher and DA's based on willingness of the farmers.

\section{Treatments and experimental setup}

The experiment comprised seven treatments were used; (1) Control, (2) NPS,(3) NPSB, (4) NPSB plus Recommended rate of Lime, (5) NPSB plus 0.75 *recommended rate of Lime,(6) NPSB plus 0.50*recommended rate of Lime and (7) NPSB plus $0.25 *$ recommended rate of lime were laid out in randomized complete block design (RCBD) replicated across Seven farmers' fields in each location with plot size of $10 \mathrm{~m} \times 10 \mathrm{~m}\left(100 \mathrm{~m}^{2}\right)$. Composite soil samples were taken from seven site randomly selected farm fields. Maize variety (BH661) seed rate of $50,000 /$ ha was used with row spacing of $80 \mathrm{~cm}$ between rows and $50 \mathrm{~cm}$ between plants as per the recommended practice for the maize crop. Fertilizer rates of $100 \mathrm{~kg} / \mathrm{ha} \mathrm{NPS,} 100 \mathrm{~kg} / \mathrm{ha}$ NPSB and $100 \mathrm{~kg} / \mathrm{ha} \mathrm{urea}$ were applied. Urea applied uniformly on all treatments and half urea applied after 45 days.

Table 1:Treatment setup of the experiment

\begin{tabular}{lll}
\hline Treatment number & Fertilizer(NPS,NPSB and Urea Kg/ha) & Lime Rates \\
\hline 1 & 0 & 0 \\
2 & $100 \mathrm{NPS}+100$ Urea & 0 \\
3 & $100 \mathrm{NPSB}+100$ Urea & 0 \\
4 & $100 \mathrm{NPSB}+100$ urea & $\mathrm{RL}$ \\
5 & $100 \mathrm{NPSB}+100$ urea & $0.75^{*} \mathrm{RL}$ \\
6 & $100 \mathrm{NPSB}+100$ urea & $0.50^{*} \mathrm{RL}$ \\
7 & $100 \mathrm{NPSB}+100$ urea & $0.25^{*} \mathrm{RL}$ \\
\hline
\end{tabular}

Note;RL=Recommended Lim

\section{Application of treatments and field management}

The field was plowed three times before planting; between the end of March and the first week of May 2017. Lastly, the field was leveled and divided into blocks which were then divided into plots. Blended fertilizer, NPSB $(18.1 \mathrm{~N}-36.1$ P2O5- $6.7 \mathrm{~S}-0.71 \mathrm{~B})$ nutrient ratio applied at of $100 \mathrm{~kg} / \mathrm{ha}$ represents balanced nutrition recommended for Maize production in the study area (EthioSIS, 2014).

\section{Soil Sampling and Lime Requirement Determination}

Initially on composite soil sample from each site was collected from 0-20 cm depth before lime application and subjected to analyses of acidity attribute and other soil physic-chemical properties. Lime Requirement (LR) of each site was determined based on exchangeable acidity (Ex. Ac). Lime application rates determined based on soil test based depending on $\mathrm{pH}$ less than 5.5. Accordingly, Lime Recommendation rates =Exchangeable Acidity *1.5*10 Kuntal/ha (Adena, 2014). Lime treatments was applied once at the beginning of the study by broadcasting and mixing with the top soil (depth 0 to $5 \mathrm{~cm}$ ), before deep incorporation by plough to the depth of $30 \mathrm{~cm}$, one months before planting.

\section{Data Collection}

Prior to conducting the experiment, three representative composite soil samples were collected from experimental site at plow depth of 0-20 cm on March /2017 and analyzed using standard laboratory procedures. In order to investigate the effect of liming to a change in $\mathrm{pH}$ and electrical conductivity, composite soil samples were again collected from each experimental plot on 2017 and were analyzed at Bedele Agricultural Research center. Agronomic data collected include plant height, biomass yield, grain yield and straw yields, and thousand grains weight and Harvest Index.

\section{Statistical analysis}

The effect of treatments on soil properties and crop parameters were statistically analyzed using Analysis System (SAS) software (SAS, 2008). When the ANOVA result showed significant difference among treatments for each parameter, least significant difference (LSD) test at 5\% probability level was applied for means separation.

\section{Economic analysis}

Economic analysis was conducted based on the procedure provided by CIMMYT (1988). Total variable cost was calculated as the sum of all cost that is variable or specific to specific treatment against the control. Net benefit was calculated by subtracting total variable cost from the gross benefit. Marginal rate of return (MRR) was 
calculated as the ratio of differences between net benefits of successive treatments to the difference between total variable costs of successive treatments. When the net benefit from preceding treatments found to be higher than net benefit from subsequent treatment, it is considered as dominated (D).

\section{Results and Discussion}

\section{Soil physical and chemical properties}

The soil $\mathrm{pH}$ of the experimental site were 4.05-5.03 (pH: H2O). In most cases soils with pH values less than 5.5 are deficient in $\mathrm{Ca}$ and/or $\mathrm{Mg}$ and also P (Marschner, 1995; Getachew and Sommer, 2000). Total nitrogen percentage of the experimental field was 0.235 and $0.385 \%$ found in low range Sahlemedhin (1999); Landon (1991). For soil to be productive, it needs to have organic carbon content in range of 1.8-3.0\% to achieve a good soil structural condition and structural stability (Charman and Roper, 2007). Thus the result agree with the Author that is $2.134-3.649 \%$. Theresult showed that Soil available P was 1.254-2.652 ppm, considered as low (Berhanu, 1980). Available P of Alfisols (Nitisols) soil is low (Mesfin, 1998).

Table 2. Selected physical and chemical properties of the experimental soil before sowing of Maize in 2017 at Omonad district in Jimma Zone.

\begin{tabular}{ccccccc}
\hline Site Number & $\mathrm{pH}$ & Av. P & TN & OC & CEC & RL kuntal/ha \\
\hline 1 & 4.71 & 2.652 & 0.314 & 3.649 & 14.97 & 5.8 \\
2 & 4.43 & 1.955 & 0.235 & 2.134 & 10.934 & 5.1 \\
3 & 4.27 & 1.939 & 0.268 & 3.635 & 15.339 & 4 \\
4 & 4.41 & 1.907 & 0.236 & 2.563 & 8.16 & 14.2 \\
5 & 4.84 & 2.158 & 0.279 & 3.173 & 9.22 & 5.6 \\
6 & 4.05 & 1.254 & 0.385 & 2.578 & 16.839 & 5.1 \\
7 & 5.03 & 1.943 & 0.378 & 3.04 & 7.483 & 5.6 \\
\hline
\end{tabular}

Note; Av.P =Available Phosphorus, TN=Total Nitrogen, $\mathrm{CEC}=$ Cation exchange Capacity and $\mathrm{RL}=$ Recommended lime

As showed table 2 the soil $\mathrm{pH}$ of experimental site was low (4.05-5.03) as explained in Recommended lime(4-14.2 Kuntal/ha) as showed (Table 2). Based on soil $\mathrm{pH}$, the soil under the study area (pH: 4.05-5.03) qualify for extremely acidic to a strongly acidic Which are $\mathrm{pH}:<4.6,4.6-5.5$ (FAO, 2008). The result showed that soil $\mathrm{pH}$ affects maize production because soil $\mathrm{pH}$ results less than the maize required proposed as FAO (2006) (pH 5.5-7). Soil results application of lime and blended fertilizer showed that increased the soil $\mathrm{pH}$ value above 5.0 at all location (Table 3 ).

Table 3. $\mathrm{pH}$ values of treatments after harvest lime and blended fertilizer effect Maize in 2017 at Omonad district in Jimma Zone.

\begin{tabular}{ll}
\hline Treatment & PH after Harvest \\
\hline control & 4.18 \\
NPS & 4.45 \\
NPSB & 4.6 \\
NPSB + Recommended Lime & 5.67 \\
NPSB $+0.75 *$ Recommended Lime & 5.31 \\
NPSB $+0.5 *$ Recommended Lime & 5.33 \\
NPSB $+0.25 *$ Recommended Rate of Lime & 5.02 \\
\hline
\end{tabular}

As showed table 3 the differences were observed between the treatments. The PH values of treatment plots that received recommended lime plus fertilizer had the highest $\mathrm{pH}$ (5.67). This result is in agreement with (Achalu,2012) who reported the ameliorating effect of lime in reducing soil acidity by increasing soil $\mathrm{pH}$ and reducing activity of aluminum ion in soil solution and reduce exchangeable acidity. However, results of soil collected at harvesting of Maize from un limed treatments indicated decreasing

\section{Effect of blended fertilizer and lime on plant height (m)}

The result revealed that the effects of blended fertilizer and Lime Application were significant on plant height (Figure 1). The plants in the control pots were shorter than the treated ones on soils from NPSB fertilizer. A maximum of $3.23 \mathrm{~m}$ mean plant height was recorded at NPSB+ Recommended Lime. In contrast, control plots exhibited significantly lower plant height $(1.96 \mathrm{~m})$ compared to all other treatments. The synergy between lime application and plant nutrition was very conspicuous on response to height increments of Maize

There was continuous and significant increase of plant height in response to the increase in applied lime. The significant Maize plant height increment in response to the increasing lime rates on acidic soils of over the control is because of the lime's ability to neutralize acidic soil toxicity effect and increase soil nutrient availability by enhancing mineralization. Liming might have reduced the detrimental effect of soil acidity on plant growth due to high concentration of $\mathrm{H}+$ and $\mathrm{Al} 3+$ ions in these acid soils in location. Activities of exchangeable basic $(\mathrm{Ca} 2+$, $\mathrm{Mg} 2+$ and $\mathrm{K}+$ ) cations; orthophosphate (H2PO4), nitrate (NO3-) and sulfate (SO42-) anions with soil organic 
matter content and their availability to plant roots might be hampered by acidifying ions (Thomas and Hargrove, 1984; Abreha et al., 2013).

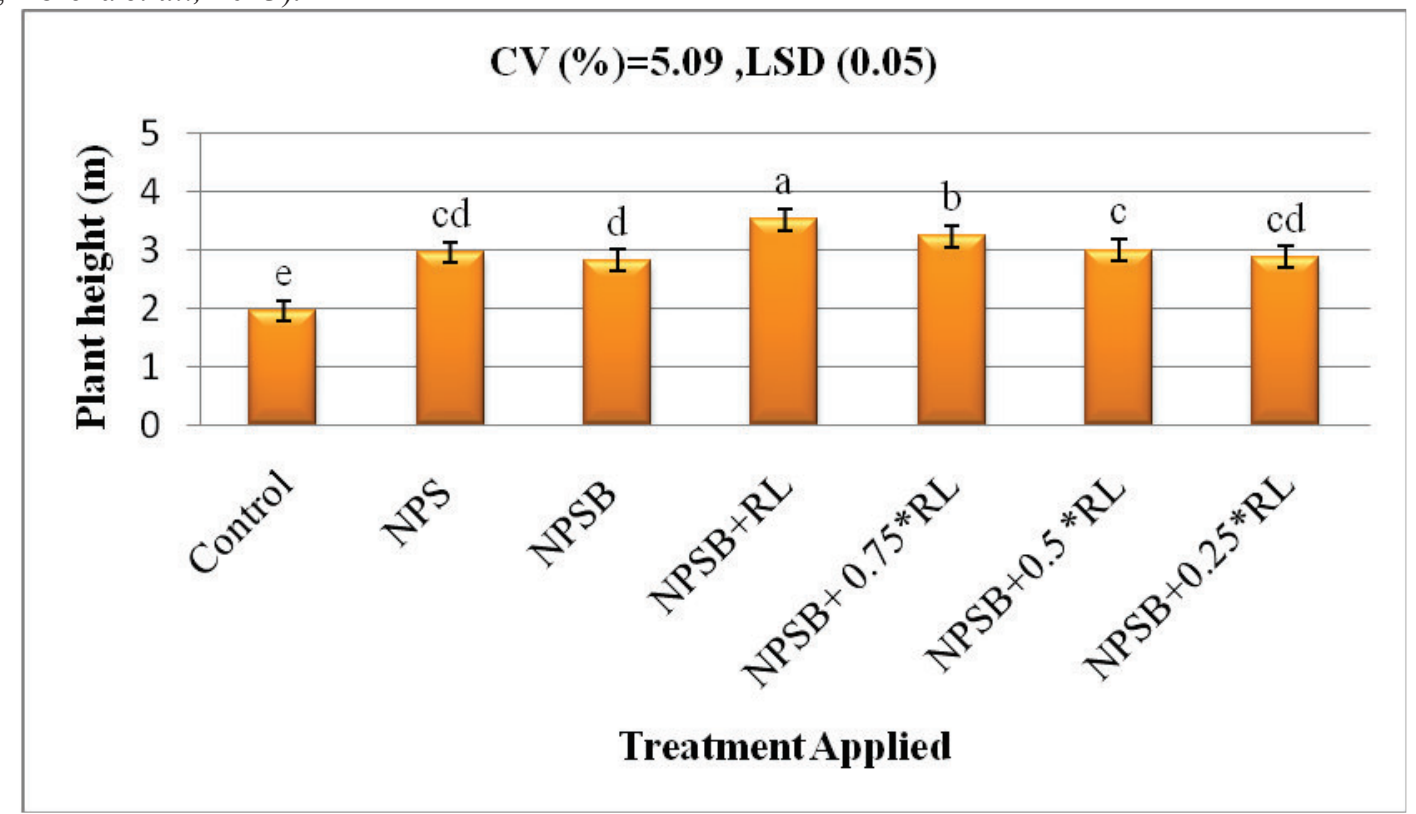

Figure 1. Effect of Lime and blended Fertilizer on plant height $(\mathrm{m})$ of maize during 2017 cropping season at Omonada district

Bars capped with same letter(s) are not significantly different at $\mathrm{P}=0.05$ according to LSD test

Effect of blended fertilizer and lime on Grain Yield of Maize (kuntal /ha)

Application of lime alone did not influence maize production on the study area. NPS and NPSB alone did not affect the yield in the district but their combined application significant affect maize yield. This increased yield might in part due to increased $\mathrm{pH}$ and reduced exchangeable aluminum and in part might be due to improved nutrients recovery as a result of lime application.

In present study, the interaction between lime rate and NPSB was significant on the grain yield (Figur 2). The highest mean grain yield of $41.72 \mathrm{kuntal} /$ ha was obtained from NPSB plus recommended rate of Lime The mean grain yield advantage obtained were varied in all considered lime application when the mean maximum grain yield gained from all location were compared with those on respective controls. As it is revealed in this study, the increased grain yields obtained on soils from location amended with different lime rates when compared to their respective controls are mainly associated with reduction of concentration of exchangeable acidity and enhancement of exchangeable bases, CEC and available P. Achalu et al. (2012); and Shiferaw and Anteneh (2014) have reported increase in maize yield as a result of increased $\mathrm{pH}$ and reduced exchangeable aluminum and in part due to improved nutrients recovery as a result of lime application.

Grain yield is a function of interaction among various yield contributing factors, which are affected differentially by the growing conditions and crop management practices. The final goal of any lime management practices in crop production is to achieve maximum economic yield, which is a complex function of individual yield components in response of the practices.

In general, the grain yield/ha was increased with the increase in lime application rates. Results obtained showed that application of blended fertilizer alone or combined with fertilizers significantly increased maize yield over the control. Therefore, instead of applying only fertilizer on acidic soils, it is better to integrate with lime for better production of maize. Application of NPSB + full dose lime significantly increased maize production over other treatment. 


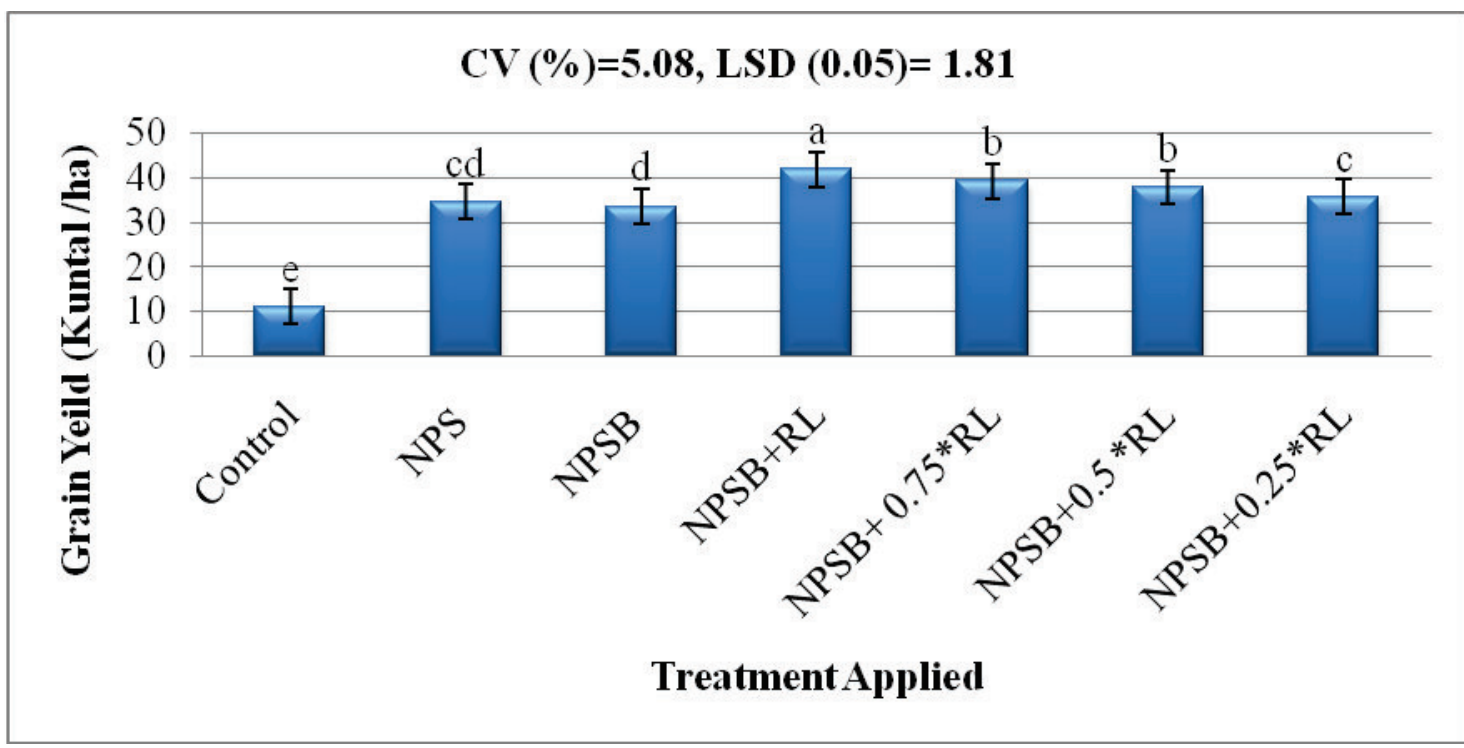

Figure 2. Effect of Lime and blended Fertilizer on Grain Yield (kuntal /ha) of maize during 2017 cropping season at Omonada district

Bars capped with same letter(s) are not significantly different at $\mathrm{P}=0.05$ according to LSD test.

\section{Effect of blended fertilizer and lime on Biomass Yield of Maize (kuntal/ha)}

The effects of lime rates and blended fertilizer highly significant effects on the Maize biomass yield (Figur 3). The lowest total biomass yield was recorded in the control treatment of soils from all the considered location.

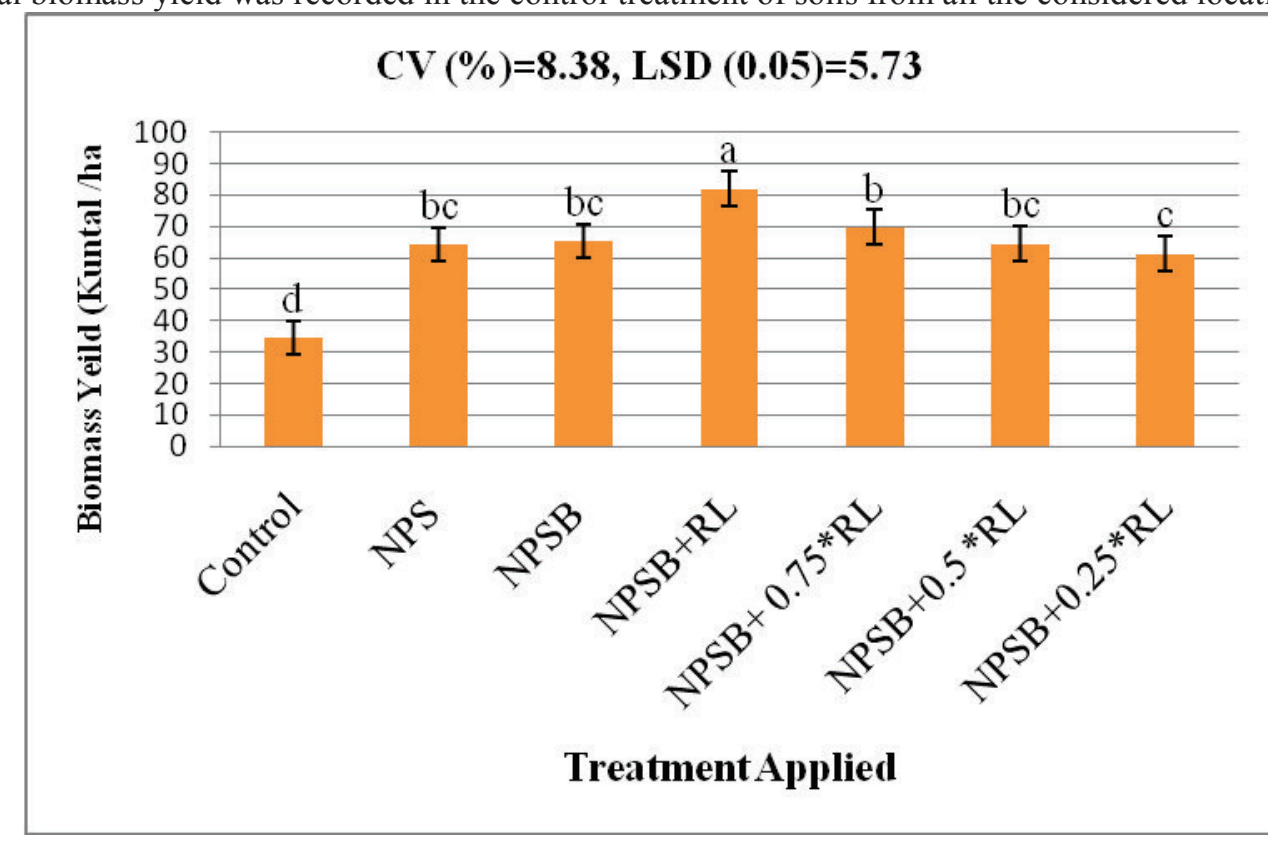

Figure 3. Effect of Lime and blended Fertilizer on Biomass Yield (kuntal/ha) of maize during 2017 cropping season at Omonada district

Bars capped with same letter(s) are not significantly different at $\mathrm{P}=0.05$ according to LSD test.

Effect of Blended Fertilizer and Lime on Harvest Index (\%) Thousand grain weight (gm) of Maize .

Harvest index was influenced significantly with integrated application of lime together with recommended blended fertilizers. The highest harvest index (58.57) was obtained with full recommended lime as compared to plots that received applied lime and lower doses lime and control plot (Table 4). In this study, harvest indices ranged from 32.34 to 58.57 that showed an increasing trend with increased combination of applied lime and blended fertilizer. The possible reason could be that application of lime with blended fertilizers might have 
increased the efficiency of barley to partition the dry matter into the reproductive seed sinks. Shiferaw and Anteneh, (2014) found that application of lime and all combinations of fertilizers, either alone or combined, significantly increased barley yield over untreated control.

Result showed that the synergistic effect of applied lime with blended fertilizer nutrient sources highly influenced thousand seed weight of Maize (Table 4). The highest thousand seed weight was recorded with T4; Full recommended lime +NPSB (771.43 g) and T5; 0.75* recommended lime +NPSB (771.22g) over control plots (442.86 g) which is attributed to better availability of nutrients and grain filling. The lowest thousand seed weight in control plots could be due to shriveled seeds that have small size which contributed to the less grain weight.

Table 4. Effect of Lime and blended Fertilizer on Harvest Index (\%)Thousand grain weight(gm) of maize during 2018 cropping season at Omonada district

\begin{tabular}{lll}
\hline Treatment & Harvest Index (\%) & $\begin{array}{l}\text { Thousand Kernel } \\
\text { Weight }(\mathrm{g})\end{array}$ \\
\hline Control & $32.34^{\text {bac }}$ & $442.86^{\mathrm{d}}$ \\
NPS & $53.83^{\mathrm{b}}$ & $664.29^{\mathrm{b}}$ \\
NPSB & $52.15^{\mathrm{b}}$ & $664.29^{\mathrm{b}}$ \\
NPSB+RL & $58.57^{\mathrm{a}}$ & $771.43^{\mathrm{a}}$ \\
NPSB+0.75*RL & $58.23^{\mathrm{a}}$ & $771.43^{\mathrm{a}}$ \\
NPSB+0.5*RL & $56.27^{\mathrm{a}}$ & $607.16^{\mathrm{c}}$ \\
NPSB+0.25*RL & $50.91^{\mathrm{b}}$ & $607.16^{\mathrm{c}}$ \\
LSD & 4.71 & 33.85 \\
CV & 8.39 & 4.46 \\
\hline
\end{tabular}

Note;- RL;Recommended lime,

Means followed by the same letter(s) are not significantly different at 5\% P level ; NPSB=Nitrogen, Phosphorus, Sulfur and Boron blended fertilizer, CV (\%) Coefficient of variation;LSD (0.05) = Least Significant Difference at $5 \% \mathrm{P}$ level

Means within a column followed by the same letter(s) are not significantly different

Economic feasibility of lime integrated and blended fertilizer on production of Maize

The results of partial budget analysis data are shown in (Table 5.) Accordingly, the highest net benefit 15160.75 Ethiopia birr /ha with Marginal rates of $556 \%$ was obtained from NPSB $+100 \%$ Recommended lime treatment followed NPSB $+75 \%$ Recommended lime treatment 14149.75 Ethiopia birr /ha with marginal rates of return of 4.19\%. This recommendation is also supported by CIMMYT (1988) which stated that farmers should be willing to change from one treatment to another if the marginal rate of return of that change is greater than the minimum acceptable rate of return. Therefore, it would be advisable for farmers in the study area to apply integrated lime at recommended lime of soil test based fertilizer recommendation 100 NPSB for better barley production and economic return in acid soils of Omonada District, Jimma south west Ethiopia.

Table 5: Economic analysis of Integrated use of lime and blended fertilizer in terms of partial budget and marginal rate of return (MRR) for barley production

\begin{tabular}{|c|c|c|c|c|c|c|c|}
\hline \multirow[b]{2}{*}{ Partial budget } & \multicolumn{7}{|c|}{ Treatment } \\
\hline & control & NPS & NPSB & $\begin{array}{l}\text { NPSB+ } \\
100 \text { RL }\end{array}$ & $\begin{array}{l}\text { NPSB+ } \\
0.75 \text { RL }\end{array}$ & $\begin{array}{l}\text { NPSB+ } \\
0.50 \text { RL }\end{array}$ & $\begin{array}{l}\text { NPSB+ } \\
\text { 0.25RL }\end{array}$ \\
\hline Average yield (Ku/ha) & 11 & 35 & 33 & 42 & 39 & 38 & 36 \\
\hline Adjusted yield $(\mathrm{Ku} / \mathrm{ha})$ & 10 & 31 & 30 & 38 & 35 & 34 & 32 \\
\hline GB (Birr/ha) & 4941 & 15530 & 15062 & 18774 & 17613 & 17010 & 16029 \\
\hline Urea cost $($ Birr/100 kg & 0 & 1080 & 1080 & 1080 & 1080 & 1080 & 1080 \\
\hline NPS cost (Birr/100 kg ) & 0 & 1350 & 0 & 0 & 0 & 0 & 0 \\
\hline NPSB Cost (Birr/100kg) & 0 & 0 & 1380 & 1380 & 1380 & 1380 & 1380 \\
\hline Labor (100 birr /day) & 0 & 0 & 0 & 400 & 300 & 200 & 100 \\
\hline TVC (Birr/ha) & 0 & 2430 & 2460 & 2860 & 2760 & 2660 & 2560 \\
\hline Net benefit & 4941 & 13100 & 12602 & 15914 & 14853 & 14350 & 13469 \\
\hline MRR \% & - & - & $\mathrm{D}$ & 556 & $\mathrm{D}$ & $\mathrm{D}$ & $\mathrm{D}$ \\
\hline
\end{tabular}

Note:- RL: Recommended lime, GB: Gross benefit, TVC: Total Variable Cost; NB: MRR\%: marginal rate of return and $\mathrm{D}$ : dominated

\section{Conclusion and Recommendations}

Crop development and potential yield depend on different environmental and soil factors. If one of the factors is limiting crop yields declined. Low yield obtained from un-limed but treated with NPS and NPSB mineral fertilizers was common in Omo Nada District. Liming is likely to have increased the $\mathrm{pH}$ to levels conducive for availability 
of most nutrients and hence its positive effect on maize growth. The effect of lime and blended fertilizer on plant height, Grain Yield, Biomass Yield were significant. The highest plant height, Grain Yield, Biomass Yield were obtained NPSB plus Recommended rate of Lime.Application of 100 recommended lime $+100 / 100 \mathrm{~kg} / \mathrm{ha}$ NPSB/urea gave the highest net return 15914 Ethiopia birr with marginal rate return of $556 \%$ which is advisable for farmers to maximize maize grain yield/ha and highest economic return on study area.

\section{Prospects}

Although the effects of blended fertilizer and lime application on Maize has been researched extensively, various aspects remain that need to be investigated. Major gaps in our knowledge of the combined impact of blended fertilizer and lime application still exist. Thus, future research endeavor should focus on:

1. The impact of combined blended fertilizer and lime application based on their properties.

2. Knowledge is also lacking about the application lime needed for amendment

\section{Competing Interests}

The author declares that there is no conflict of interests regarding the publication of this paper.

\section{Acknowledgments}

The author thanks Jimma CASCAPE Project for Finance support. Also the authors gave greatfull thanks to Professor Gezagn Barech Jimma Univesty CASCAPE Project Cordinoter for his advise. I also would like acknowledge Bedele Agricultural Research Center for their cooperation during field work and soil laboratory analysis.

\section{REFERENCES}

Achalu Chimdi, Heluf Gebrekidan, KibebewKibret and AbiTadesse. 2012. Effects of Liming on Acidity-Related Chemical Properties ofSoils of Different Land Use Systems in Western Oromia, Ethiopia. World Journal of Agricultural Sciences 8 (6): 560-567

Adane Buni., 2014. Effects of liming acidic soils on improving soil properties and yield of haricot bean. Journal of Environmental \& Analytical Toxicology, 5:1-4

Anetor and Ezekiel Akinkunmi Akinrinde( 2007), "Lime effectiveness of some fertilizers in a tropical acid alfisol", University of Ibadan, Ibadan, Nigeria.

Berhanu, D. 1980. The Physical Criterion and Their Rating Proposed for Land Evaluation in the Highland Regions of Ethiopia, Land Uses Planning and Regulatory Department, Ministry of Agriculture, Addis Ababa, Ethiopia.

Charman, P and Rope, M. 2007. Soil Organic Matter. pp. 276-285. In Charman P. and Murphy B. (Eds.) Soils, Their Properties and Management. 3rd Edition. Melbourne: Oxford University Press

CIMMYT (International maize and wheat improvement Center) (1998): From agronomic data to farmers recommendations. Economics training manual. Completely revised edition. D. F. Mexico

Dercon, S., Gilligan, D. O., Hoddinott, J. and Woldehanna, T., 2009. The impact of agricultural extension and roads on poverty and consumption growth in fifteen Ethiopian villages. American Journal of Agricultural Economics, 91: 1007-1021

EthioSIS (Ethiopian Soil Information System), "Soil fertility status and fertilizer recommendation in, Ethiopia. July 2014

Eyasu Elias. 2016. Soils of Ethiopian highlands, Geomorphology and properties.

FAO (Food and Agriculture Organization of the UnitedNations), World Reference Base for Soil Resources: A Framework for International Classification, Correlation and Communication, World Soil Resources Reports No. $103,2^{\text {nd }}$ edition, 2006.

FAO (Food and Agriculture Organization), Plant nutrition for food security. A guide for integrated nutrient management. Rome, Italy: FAO (Food and Agriculture Organization), 2008.

Food and Agriculture Organization Corporate Statistical Database (FAOSTAT). 2017. Statistical databases and data-sets of the Food and Agriculture Organization of the United Nations.

Getachew, A and Chilot, Y. 2009. Integrated Nutrient Management in Faba Bean and Wheat on Nitisols of central Ethiopian Highlands. Research Report No. 72. Ethiopian Inst. of Agric. Res. Addis Ababa, Ethiopia, pp. 24.

Getachew, A and Sommer, K. 2000. Optimization of the efficiency of phosphate fertilizers in acidic- ferralitic soils of the humid tropics. Ethiopian J. of Natu. Reso. 2: 63-77.

Landon, JR.(Ed.) 1991. Booker tropical soil manual: A Handbook for soil survey and Agricultural Land Evaluation in the tropics and sub tropics. Longman scientific and Technical, Essex, New York.47 p

Macauley, H., 2015. Cereal crops: rice, maize, millet, sorghum, and wheat: background paper. Conference on 'Feeding Africa' Dakar, Senegal, 21-23 October 2015.

Marschner, H. (1995). Mineral nutrition of higher plants, 2nd edition, Academic press, Michigan University Mesfin A (1998) Nature and Management of Ethiopian soils. Alemaya University of Agriculture, Ethiopia 272. 
Shiferaw Bokore and Anteneh Fikadu (2014). Lime and NPK Effect On Soil Acidity and Yield of Barely in different Acid Soils of Southern Region, Ethiopia .International Journal of Natural Sciences Research 2(7): $113-122$

Taye B (2007): An overview of acid soils their management in Ethiopia paper presented in the third International Workshop on water management (Wterman) project, September, 19-21, 2007, Haromaya, Ethiopia.

Thomas GW and Hargrove WL (1984). The chemistry of soil acidity. pp. 3-56. In: Adams, F. (ed.). Soil Acidity and Liming. American Society of Agronomy, Inc., Madison, WI, USA

Wassie and B. Shiferaw, "Mitigation of soil acidity and fertility decline challenges for sustainable livelihood improvement: Evidence from Southern region of Ethiopia, 2009.

Zelleke G, Agegnehu G, Abera D and Rashid S (2010) Fertilizer and Soil Fertility Potential in Ethiopia: Constraints and opportunities for enhancing the system. Addis Ababa: International Food Policy Research Institute. 